\title{
ASSESSMENT OF SEAFOOD PROCESSING SLUDGE AFTER COMPOSTING ON GROWTH OF TAGETES PATULA L.
}

\author{
Nguyen Van Tho ${ }^{1}$, Tran My Vien ${ }^{2}$, Huynh Phan Khanh Binh ${ }^{3}$
}

\begin{abstract}
Sludge of seafood processing factories discharged directly into the environment can lead to environmental pollution. Research on the use of seafood processing sludge as compost for agriculture in the Mekong Delta is encouraged. The objectives of this study were (1) to evaluate the chemical composition of seafood processing sludge after 60 days composting and (2) to evaluate the growth of Tagetes patula L planted with composted sludge. The sludge composting experiment was carried out with 3 treatments: sludge + Trichoderma fungi; sludge + chicken manure + Trichoderma fungi; sludge + straw + chicken manure + Trichoderma fungi. The results showed that the treatment of sludge + straw + chicken manure + Trichoderma fungi had a better quality than the other two treatments. The $\mathrm{pH}$, TC, TN, $\mathrm{NH}_{4}^{+}, \mathrm{NO}_{3}^{-}, \mathrm{TP}, \mathrm{PO}_{4}^{3-}$ and heavy metal $(\mathrm{Pb}, \mathrm{Cd}, \mathrm{Cr}, \mathrm{Cu}, \mathrm{Ni}, \mathrm{Zn}$ and $\mathrm{Hg}$ ) contents of sludge meet the environmental standard of Viet Nam (10TCN526:2002). E. coli and Salmonella were not present at the end of the composting experiment. Tagetes patula $L$ grew and flowered on all 4 treatments: control - composted straw; sludge + Trichoderma fungi; sludge + chicken manure + Trichoderma fungi; sludge + straw + chicken manure + Trichoderma fungi. However, Tagetes patula L grew best on the sludge + Trichoderma fungi experimental condition.
\end{abstract}

Keywords: composting, seafood sludge, Tagetes patula L, Trichoderma.

\section{INTRODUCTION}

Viet Nam is one of the largest aquaculture producers in the world. Seafood products are

\footnotetext{
${ }^{1,3}$ Faculty of Urban-Infrastructure Engineering, Mien Tay Construction University

${ }^{2}$ Faculty of Environment and Natural Resources, Can Tho University

Email: nguyenvantho@mtu.edu.vn

Received date: $20^{t h}$ August 2020; Revised date: $23^{\text {rd }}$ November 2020; Accepted date: $25^{t h}$ December 2020
}

exported to 164 countries and territories with turnover estimated approximately 7 billion USD. In particular, Pangasius and shrimp are still the two main products of the industry with export turnover estimated at 1.67 billion USD and 3.1 billion USD, respectively [1]. The Mekong Delta contributes greatly to total national aquaculture products for domestic consumption and export. Seafood processing factories have also increased rapidly in the period from 2001 to 2015 , especially many large-scale factories. The Mekong Delta had nearly 280 seafood processing factories, accounting for $47 \%$ of the total of Viet Nam [2]. Although the seafood processing industry has contributed significantly to the domestic economy through job creation and trade, it also has negative environmental impacts. The annual average sludge discharged in Viet Nam from this industry is about 313,170 tons. It was reported that $75 \%$ of industrial effluent including that from seafood processing industry was being discharged into rivers without treatment in Viet Nam [3]. These effluents usually have a relatively high organic content due to contamination with blood, fish heads, intestinal remains and flesh pieces [4]. The effluent quality of the seafood processing industry greatly depends on the type of input material (fish, shrimp and so on) being processed and the type of processing undertaken. This industry generates waste slurry which presents a significant disposal problem and can lead to serious environmental pollution without treatment. Research on the use of seafood processing sludge combined with local available agricultural residues as compost to reuse their nutrients for agriculture in the Mekong Delta is encouraged. Tagetes patula $\mathrm{L}$ is selected in this study. It is easy to grow and commonly used as an ornamental garden plant in ceremonies and is displayed in houses, especially on the occasion of the Lunar New Year, because flowers of Tagetes 
patula $\mathrm{L}$ mean a wish for health, longevity and luck for family members. Moreover flowers of Tagetes patula $\mathrm{L}$ contain active ingredients that help to repel harmful insects [5].

The objectives of this study were (1) to evaluate the chemical composition of seafood processing sludge after composting for 60 days and (2) to evaluate the growth of Tagetes patula $\mathrm{L}$ when planted with composted sludge.

\section{MATERIALS AND METHODS}

A. Seafood processing sludge, rice straw and chicken manure

Seafood processing sludge was collected from the wastewater treatment system of the seafood processing industrial zone, in Chau Thanh District, Soc Trang Province, Viet Nam. Rice straw and chicken manure were taken from agricultural farming households in Cai Rang District, Can Tho City, Viet Nam. The initial characteristics of these input materials such as humidity (\%), $\mathrm{CHC}$ $(\%), \mathrm{C}(\%), \mathrm{TN}(\%)$ and $\mathrm{C} / \mathrm{N}$ were determined as described in Standard Methods [6] (Table 1).

Heavy metal $(\mathrm{Pb}, \mathrm{Cd}, \mathrm{Cr}, \mathrm{Cu}, \mathrm{Ni}, \mathrm{Zn}$ and $\mathrm{Hg})$ contents in the seafood processing sludge before composting were also analysed as shown in Table 2.

The content of all heavy metals in the sludge before composting met Vietnamese Standard (10TCN526:2002), so they were not analyzed at the end of the experiment. E. coli and Salmonella in the initial materials before composting were also analyzed, shown in the Table 3 .

\section{B. Trichoderma fungi and Tagetes patula $L$}

Trichoderma $\left(20-30 \mathrm{~g} / \mathrm{m}^{3}, 108 \mathrm{CFU} / \mathrm{g}\right)$ was produced at Department of Plant Protection, Faculty of Agriculture and Applied Biology, Can Tho University. Tagetes patula L. was provided from a bonsai company in Can Tho City, Viet Nam.

\section{C/N ratio}

It is well-known that $\mathrm{C} / \mathrm{N}$ ratio is a key parameter for the composting process. The optimal $\mathrm{C} / \mathrm{N}$ ratio in this composting was $25 / 1$. This ratio would decompose organic materials better [7].
For each treatment, the amount of sludge was the main material (accounting for about $50 \%$ of the weight of the compost), the amount of rice straw and chicken manure was adjusted in each treatment to ensure a $\mathrm{C} / \mathrm{N}$ ratio of $25 / 1$.

\section{Experimental design}

Composting was carried out in piles with a volume of about $1 \mathrm{~m}^{3}$ for 60 days. Each pile was covered with plastic tarpaulin to avoid sun and rain. Composting was carried out with 3 treatments in which each treatment was repeated 3 times: sludge + Trichoderma fungi (T1); sludge + chicken manure + Trichoderma fungi (T2); sludge + straw + chicken manure + Trichoderma fungi (T3). At the beginning of the incubation, $30 \mathrm{~g}$ of Trichoderma fungi powder was dissolved in 150 litres of water and sprinkled on the compost pile. The moisture content of the compost pile was also monitored and water was added as needed to maintain water content of $60-70 \%$. In the first 45 days, the compost pile was well mixed once a week. Measurements were made of $\mathrm{pH}, \mathrm{TC}, \mathrm{TN}$, $\mathrm{NH}_{4}^{+}, \mathrm{NO}_{3}^{-}, \mathrm{TP}, \mathrm{PO}_{4}^{3-}$ after compost preparation and at the end of composting experiments (the 60th day). E. coli and Salmonella were analysed at the end of experiment. Tagetes patula L. plants were grown in organic soil for 14 days, and then they were transferred to bamboo pots for the experiment for 60 days. The experiment was carried out with 4 treatments and 4 repetitions for each treatment: control - composted straw; sludge + Trichoderma fungi; sludge + chicken manure + Trichoderma fungi and sludge + straw + chicken manure + Trichoderma fungi. Tagetes patula $\mathrm{L}$. was also watered 2 times per day and supplied with a little nitrogenous fertilizer to help growth.

\section{E. Assessment of compost}

Compost quality was assessed through physical and chemical parameters and nutrient $(\mathrm{pH}, \mathrm{TC}$, $\left.\mathrm{TN}, \mathrm{NH}_{4}^{+}, \mathrm{NO}_{3}^{-}, \mathrm{TP}, \mathrm{PO}_{4}^{3-}\right)$, microorganisms (E. coli and Salmonella) and heavy metal concentrations $(\mathrm{Pb}, \mathrm{Cd}, \mathrm{Cr}, \mathrm{Cu}, \mathrm{Ni}, \mathrm{Zn}$ and $\mathrm{Hg})$, compared to the environmental standard of Vietnam (10TCN526:2002). 
Table 1. Initial properties of input materials

\begin{tabular}{|l|c|c|c|c|c|}
\hline Materials & Humidity (\%) & CHC (\%) & C (\%) & TN (\%) & C/N \\
\hline Sludge & 86.8 & 62.5 & 36.2 & 4.5 & 8.1 \\
\hline Straw & 14.0 & 85.5 & 49.8 & 0.8 & 62.2 \\
\hline Chicken manure & 65.7 & 80.2 & 46.5 & 6.6 & 7.1 \\
\hline
\end{tabular}

Table 2. Heavy metals in the sludge before composting

\begin{tabular}{|c|c|c|}
\hline Number & Metals & Content (mg/kg) \\
\hline 1 & $\mathrm{~Pb}$ & 4.7 \\
\hline 2 & $\mathrm{Cd}$ & - \\
\hline 3 & $\mathrm{Cr}$ & 15.4 \\
\hline 4 & $\mathrm{Cu}$ & 50.2 \\
\hline 5 & $\mathrm{Ni}$ & 6.1 \\
\hline 6 & $\mathrm{Zn}$ & 44.8 \\
\hline 7 & $\mathrm{Hg}$ & - \\
\hline
\end{tabular}

(Note : “-” Not detected)

Table 3. E. coli and Salmonella in input materials before composting

\begin{tabular}{|l|c|c|}
\hline Materials & E. Coli (CFU/g) & Salmonella $(\mathrm{CFU} / \mathrm{g})$ \\
\hline Sludge & 1.48 & - \\
\hline Rice straw & - & - \\
\hline Chicken manure & 2.78 & 2.30 \\
\hline
\end{tabular}

(Note : “-” Not detected)

\section{F. Assessment of Tagetes patula L growth.}

Plant height, number of flowers, number of flower buds, flower diameter and flower durability were measured.

\section{G. Analytical methods}

The $\mathrm{pH}$ was measured in slurry with a ratio of solids: water of 1:10 (w/v) using $\mathrm{pH}$ meter (Model WTW pH 720). TC and TN content were analyzed with an elemental analyzer (Vario MACRO CN Elemental analyzer). For TP and heavy metals $(\mathrm{Pb}, \mathrm{Cd}, \mathrm{Cr}, \mathrm{Cu}, \mathrm{Ni}, \mathrm{Zn}$ and $\mathrm{Hg}$ ) compost was first digested in a mix of nitric acidperchloric acid [6], and then measured using a spectrophotometer (Model DR 5000) and ICPMS (Model NexION 300X, Perkin Elmer), respectively. $\mathrm{N}-\mathrm{NH}_{4}^{+}$and $\mathrm{N}-\mathrm{NO}_{3}^{-}$, were determined via DR 5000 spectrophotometer [8].

\section{H. Data analysis}

SPSS 20.0 statistical software was used to process data, comparing averages of treatments by ANOVA variance analysis and comparing differences by LSD at $95 \%$ confidence level.

\section{RESULTS AND DISCUSSION}

\section{A. Assessment of compost}

E. coli and Salmonella were monitored at the first day and at the end of the experiment (60th days) of all treatments: (T1): sludge + Trichoderma fungi; (T2): sludge + chicken manure + Trichoderma fungi; (T3): sludge + straw + chicken manure + Trichoderma fungi. The results are shown in Table 4. 
The presence of $E$. coli was detected only on the $1^{\text {st }}$ day in all treatments; E. coli was not detectable in any treatment at the 60th days. Both E. coli and Salmonella were below our detection limit in all treatments after 60 days. Ruiz-Barrera et al. [9] reported that higher temperatures generated by stacking litter, and ammonia produced by the degradation of uric acid, urea and other nitrogenous compounds are known to be bactericidal for pathogens such as Salmonella and $E$. coli in the compost containing poultry manure.

The $\mathrm{pH}$ values of the compost mixtures ranged from 6.52 to 7.28 at the beginning and 6.58 to 6.94 at the end of the process as shown in Table 5. At the end of the process, $\mathrm{pH}$ values met the environmental standard of Viet Nam (10TCN526:2002)

$\mathrm{N}-\mathrm{NO}_{3}^{-}$values at the beginning and the end of the composting process are presented in Table 6. There was a significant increase of $\mathrm{N}$ $\mathrm{NO}_{3}^{-}$amount in the compost after 60 days of the process. This is an indication of compost maturity. Temperature was not measured in this experiment, but it usually rises in the composting process. Villar et al. [10] reported that increasing composting temperature could be an important factor influencing organic matter mineralization and $\mathrm{N}_{-} \mathrm{NO}_{3}^{-}$formation. Moreover, the Trichoderma fungi supplement probably improved the amount of $\mathrm{N}^{-\mathrm{NO}_{3}^{-}}$, by promoting biological nitrification in the useful microbial adding compost [11].

The $\mathrm{N}-\mathrm{NH}_{4}^{+}$values at the beginning and the end of the composting process are presented in Table 7. The final values decreased in $\mathrm{T} 2$ and T3 compared to initial values. Raj and Antil [12] reported that nitrification, ammonia evaporation and immobilization by microorganisms during decomposition of organic substances could cause this reduction. However, the final value increased in T1 compared to the initial value. Sludge from seafood processing factories had a high percentage of total nitrogen but low decomposition and low $\mathrm{C} / \mathrm{N}$ ratio, so nitrogen could be lost in $\mathrm{NH}_{3}$ form [7].

The $\mathrm{P}_{-} \mathrm{PO}_{4}^{3-}$ values at the beginning and end of the composting process are presented in Table 8. The final values increased in all treatments compared to the initial values. This increase in $\mathrm{P}$ -
$\mathrm{PO}_{4}^{3-}$ content in the composting process is due to microbial activity that transforms phosphorus in organic form into inorganic form which is useful for plants $\left(\mathrm{P}_{2} \mathrm{O}_{5}\right)$.

The TC, TN and TP at the beginning and end of the composting process are presented in Table 9.

There was a significant decrease of TC (\%) in all treatments at the end of composting process. This decrease was due to the organic matter decomposed by microorganisms and converted into $\mathrm{CO}_{2}, \mathrm{H}_{2} \mathrm{O}$, salts and energy, $\mathrm{CO}_{2}$ released during the composting process, making the total of carbon content TC $(\%)$ decrease. Significant increases in TP (\%) occurred in all treatments at the end of composting process, perhaps due to the loss of dry mass during the composting process [13]. There was no significant difference of $\mathrm{TN}(\%)$ among treatments. TN (\%) values ranged from 2.32 to 2.78 . TC $(\%)$ and $\mathrm{TN}(\%)$ meet 10TCN526:2002 (not less than 2.5\%), but TP (\%) was under 10TCN526:2002 (not less than $2.5 \%)$.

In general, the $\mathrm{T} 3$ treatment (sludge + straw + chicken manure + Trichoderma fungi) had a better compost quality than the other two treatments (T1, T2), compared to the environmental standard of Viet Nam (10TCN526:2002).

\section{B. Assessment of Tagetes patula $L$.}

Values of plant height, number of flowers, number of flower buds, flower diameter and flower durability of Tagetes patula $\mathrm{L}$ at the end of the experiment (60 days) are presented in Table 10.

Tagetes patula $\mathrm{L}$ grew and flowered in all treatments. However, T1 (Sludge + Trichoderma) was marginally better than other treatments. In this study, $\mathrm{N}_{-} \mathrm{NH}_{4}^{+}$in $\mathrm{T} 1$ (Sludge + Trichoderma) at the end of the composting process was significant higher than in other treatments, while $\mathrm{N}$ $\mathrm{NO}_{3}^{-}$in $\mathrm{T} 1$ was significant lower than $\mathrm{N}^{-\mathrm{NO}_{3}^{-}}$in other treatments. This could be one of the crucial factors improving the growth of Tagetes patula $\mathrm{L}$. 
Table 4. E. coli and Salmonella were analyzed at day 1 and at the end of experiment (day 60)

\begin{tabular}{|c|c|c|c|c|}
\hline \multirow{2}{*}{ Treatment } & \multicolumn{2}{|c|}{ E. coli $($ Log CFU/g) } & \multicolumn{2}{c|}{ Salmonella $($ Log CFU/g) } \\
\cline { 2 - 5 } & The $1^{\text {st }}$ day & The $60^{\text {th }}$ day & The $1^{\text {st }}$ day & The $60^{\text {th }}$ day \\
\hline T1 & 1.48 & - & - & - \\
\hline T2 & 1.78 & - & - & - \\
\hline T3 & 1.95 & - & - & - \\
\hline
\end{tabular}

(Notes : - Not detected)

Table 5. $\mathrm{pH}$ at the 1 st day and at the end of the process

\begin{tabular}{|c|c|c|}
\hline Treatment & The $1^{\text {st }}$ day & The $60^{\text {th }}$ day \\
\hline T1 & $6.52^{\mathrm{aA}} \pm 0.21$ & $6.58^{\mathrm{aA}} \pm 0.10$ \\
\hline$T 2$ & $6.71^{\mathrm{aA}} \pm 0.11$ & $6.60^{\mathrm{aA}} \pm 0.01$ \\
\hline$T 3$ & $7.28^{\mathrm{aB}} \pm 0.23$ & $6.94^{\mathrm{aB}} \pm 0.02$ \\
\hline
\end{tabular}

(Notes: Values in the same column with different upper-case letters (A-C) are significantly different at $p<0.05$. Values in the same row with different letters $(a-b)$ are significantly different at $p<$ $0.05)$

Table $6 . \mathrm{N}^{-\mathrm{NO}_{3}^{-}}$at the 1 st day and at the end of the process

\begin{tabular}{|c|c|c|}
\hline Treatment & The $1^{\text {st }}$ day & The $60^{\text {th }}$ day \\
\hline T1 & $0.78^{\mathrm{a}} \pm 0.17$ & $84.66^{\mathrm{bA}} \pm 6.30$ \\
\hline T2 & $0.83^{\mathrm{a}} \pm 0.10$ & $149.55^{\mathrm{bB}} \pm 4.82$ \\
\hline T3 & $1.62^{\mathrm{a}} \pm 0.13$ & $369.37^{\mathrm{b}} \pm 5.10$ \\
\hline
\end{tabular}

(Notes: Values in the same column with different upper-case letters $(A-C)$ are significantly different at $P<0.05$. Values in the same row with different letters $(a-b)$ are significantly different at $P<$ $0.05)$

Table 7. $\mathrm{N}-\mathrm{NH}_{4}^{+}$values at the 1 st day and at the end of the process

\begin{tabular}{|c|c|c|}
\hline Treatment & The $1^{\text {st }}$ day & The $60^{\text {th }}$ day \\
\hline T1 & $129.82^{\mathrm{aA}} \pm 1.82$ & $215.04^{\mathrm{bA}} \pm 4.04$ \\
\hline T2 & $153.21^{\mathrm{aB}} \pm 3.60$ & $90.42^{\mathrm{bB}} \pm 4.97$ \\
\hline$T 3$ & $191.03^{\mathrm{aC}} \pm 6.70$ & $150.93^{\mathrm{bC}} \pm 5.61$ \\
\hline
\end{tabular}

(Notes: Values in the same column with different upper-case letters $(A-C)$ are significantly different at $P<0.05$. Values in the same row with different letters $(a-b)$ are significantly different at $P<$ 0.05)

Table 8. $\mathrm{P}_{-} \mathrm{PO}_{4}^{3-}$ values at the 1 st day and at the end of the process

\begin{tabular}{|c|c|c|}
\hline Treatment & The $1^{\text {st }}$ day & The $60^{\text {th }}$ day \\
\hline T1 & $358.11^{\mathrm{aA}} \pm 5.70$ & $548.65^{\mathrm{bA}} \pm 0.69$ \\
\hline $\mathrm{T} 2$ & $313.42^{\mathrm{aA}} \pm 3.45$ & $438.36^{\mathrm{bB}} \pm 0.27$ \\
\hline $\mathrm{T} 3$ & $259.28^{\mathrm{aB}} \pm 4.95$ & $733.02^{\mathrm{bC}} \pm 6.74$ \\
\hline
\end{tabular}

(Notes: Values in the same column with different upper-case letters $(A-C)$ are significantly different at $p<0.05$. Values in the same row ith different letters $(a-b)$ are significantly different at $p<0.05$ ) 
Table 9. The TC, TN and TP values at the beginning and end of the composting process

\begin{tabular}{|c|c|c|c|c|c|c|}
\hline & \multicolumn{2}{|c|}{ TC $(\%)$} & \multicolumn{2}{c|}{ TN $(\%)$} & \multicolumn{2}{c|}{ TP $\%)$} \\
\hline Treatment & The $1^{\text {st }}$ day & The $60^{\text {th }}$ day & The $1^{\text {st }}$ day & The $60^{\text {th }}$ day & The $1^{\text {st }}$ day & The $60^{\text {th }}$ day \\
\hline T1 & $36.37^{\mathrm{aA}} \pm 0.54$ & $20.12^{\mathrm{bA}} \pm 0.84$ & $4.45^{\mathrm{aA}^{\mathrm{A}}} \pm 0.13$ & $2.32^{\mathrm{bA}} \pm 0.05$ & $1.26^{\mathrm{aA}} \pm 0.35$ & $1.68^{\mathrm{bA}} \pm 0.03$ \\
\hline T2 & $32.63^{\mathrm{aB}} \pm 1.50$ & $21.72^{\mathrm{bA}} \pm 1.12$ & $2.38^{\mathrm{a}^{\mathrm{B}} \pm 0.16}$ & $2.78^{\mathrm{bA}} \pm 0.08$ & $1.27^{\mathrm{aA}} \pm 0.02$ & $1.49^{\mathrm{b}} \pm 0.02$ \\
\hline T3 & $54.09^{\mathrm{a}} \pm 0.53$ & $26.19^{\mathrm{b}} \pm 1.75$ & $2.19^{\mathrm{B}} \pm 0.20$ & $2.63^{\mathrm{bA}} \pm 0.07$ & $1.37^{\mathrm{aB}} \pm 0.02$ & $1.79^{\mathrm{bC}} \pm 0.05$ \\
\hline
\end{tabular}

(Notes: Values in the same column with different upper-case letters $(A-C)$ are significantly different at $P<0.05$. Values in the same row with different letters $(a-b)$ are significantly

different at $P<0.05$ )

Table 10. Values for Tagetes patula $\mathrm{L}$ assessment at the end of the experiment (60 days)

\begin{tabular}{|l|c|c|c|c|}
\hline \multirow{2}{*}{ Tagetes patula L } & \multicolumn{4}{|c|}{ Treatment } \\
\cline { 2 - 5 } & CT & T1 & T2 & T3 \\
\hline Plant height $(\mathrm{cm})$ & $66.48^{\mathrm{a}} \pm 0.51$ & $72.13^{\mathrm{b}} \pm 0.15$ & $61.18^{\mathrm{c}} \pm 0.21$ & $62.73^{\mathrm{d}} \pm 0.65$ \\
\hline Numbers of flower bud & $30.25^{\mathrm{a}} \pm 0.50$ & $35.50^{\mathrm{b}} \pm 0.58$ & $20.25^{\mathrm{c}} \pm 0.50$ & $27.75^{\mathrm{d}} \pm 0.50$ \\
\hline Numbers of flower & $24.75^{\mathrm{a}} \pm 2.22$ & $29.25^{\mathrm{b}} \pm 1.71$ & $15.50^{\mathrm{c}} \pm 1.73$ & $21.50^{\mathrm{d}} \pm 1.91$ \\
\hline Flowering rate $(\%)$ & $81.80^{\mathrm{a}} \pm 7.00$ & $82.38^{\mathrm{a}} \pm 4.31$ & $76.61^{\mathrm{a}} \pm 9.17$ & $77.48^{\mathrm{a}} \pm 6.73$ \\
\hline Flower diameter $(\mathrm{cm})$ & $7.18^{\mathrm{a}} \pm 0.29$ & $9.53^{\mathrm{b}} \pm 0.10$ & $6.40^{\mathrm{c}} \pm 0.29$ & $7.33^{\mathrm{a}} \pm 0.28$ \\
\hline Flower durability (days) $\left({ }^{*}\right)$ & 15.75 & 22.25 & 10.25 & 17.75 \\
\hline
\end{tabular}

(Notes: $C T=$ Control, $T 1=$ Sludge + Trichoderma, $T 2=$ Sludge + Chicken manure + Trichoderma, $T 3=$ Sludge + Straw + Chicken manure +Trichoderma.$(*)$ Flower durability was recorded from the time as bloomed flowers until the time as the faded flowers to $50 \%$ on Tagetes patula L. Values in the same row with different letters $(a-d)$ are significantly different at $p<0.05)$

\section{CONCLUSIONS}

Seafood waste sludge can be used to produce compost when mixed with straw, chicken manure and Trichoderma fungi. This treatment had better compost quality than the treatment of sludge + Trichoderma and the treatment of sludge + chicken manure + Trichoderma fungi after 60 days of experiment. The $\mathrm{pH}, \mathrm{TC}, \mathrm{TN}, \mathrm{NH}_{4}^{+}$, $\mathrm{NO}_{3}^{-}, \mathrm{TP}, \mathrm{PO}_{4}^{3-}$ and heavy metals $(\mathrm{Pb}, \mathrm{Cd}, \mathrm{Cr}$, $\mathrm{Cu}, \mathrm{Ni}, \mathrm{Zn}$ and $\mathrm{Hg}$ ) all met the environmental standard of Vietnam (10TCN526:2002). E. coli and Salmonella were not present at the end of the composting experiment. Tagetes patula $\mathrm{L}$ grew and flowered in all 4 treatments: control - composted straw; sludge + Trichoderma fungi; sludge + chicken manure + Trichoderma fungi; sludge + straw + chicken manure + Trichoderma fungi. However, Tagetes patula $\mathrm{L}$ grew best on the sludge + Trichoderma fungi experimental condition.

\section{REFERENCES}

[1] VASEP (Vietnam Association of Seafood Exporters and Producers). Fishery production results in 2016 and orientation of seafood production and export in 2017 and toward 2020. VASEP. 2016.

[2] Hai L.H. Mekong Delta develops seafood processing industry in chain. Vietnam Plus. 2014. Available from: https://www.vietnamplus.vn/dbsclphat-trien-cong-nghiep-che-bien-thuy-san-theochuoi/242217.vnp [Accessed 20/04/2021].

[3] ITA (The International Trade Administration). Vietnam - Environmental and Pollution Control Equipment and Services. 2017. Available from: https://www.export.gov/ [Accessed 27/4/2021].

[4] Jayashree C, Tamilarasan K, Rajkumar M, Arulazhagan P, Yogalakshmi KN, Srikanth M, Banu JR. Journal of Environmental Management. 2016; 180:351358.

[5] FAO. Cách trồng hoa vạn thọ têt nở hoa "siêu đẹp" cho bà con. 2020 Available from: https://www.fao.org.vn/trong-trot/cach-tronghoa-van-tho-tet/\#So_luoc_ve_cay_hoa_van_tho [Accessed 1/4/2021] (in Vietnamese language).

[6] APHA. Standard Methods for the Examination of Water and Wastewater, 21st ed. American Public Health Association. 2005.

[7] Wang X, Lu X, Li F, Yang G. Effects of Temperature 
and Carbon-Nitrogen (C/N) Ratio on the Performance of Anaerobic Co-Digestion of Dairy Manure, Chicken Manure and Rice Straw: Focusing on Ammonia Inhibition. PLOS ONE. 2014 ; 9(5):e97265.

[8] Mulvaney R. L. Nitrogen-Inorganic Forms. In D. L. Sparks, A. L. Page, P. A. Helmke, R. H. Loeppert, P. N. Soltanpoor, M. A. Tabatabai, C. T. Johnston, M. E. Sumner (Eds.). Methods of Soil Analysis, Part 3, Chemical Methods. SSSA Book Series No. 5, Madison, WI: SSSA. 1996.

[9] Ruiz-Barrera O, Ontiveros-Magadan M, Anderson R.C, Byrd J. A, Hume M.E, Latham E.A et al. Nitro-treatment of composted poultry litter; effects on Salmonella, E. coli and nitrogen metabolism. Bioresource Technology. 2020; 310:123459. DOI: https://doi.org/10.1016/j.biortech.2020.123459.
[10] Villar I, Alves D, Mato S. Product quality and microbial dynamics during vermicomposting and maturation of compost from pig manure. Waste Manage. 2017; 69:498-507.

[11] Zhao Y, Li W, Chen L, Meng L, Zheng Z. Effect of enriched thermotolerant nitrifying bacteria inoculation on reducing nitrogen loss during sewage sludge composting. Bioresource Technology. 2020; 311:123461. DOI: https://doi.org/10.1016/j.biortech.2020.123461.

[12] Raj D, Antil R.S. Evaluation of maturity and stability parameters of composts prepared from agro-industrial wastes. Bioresource Technology. 2011; 102(3):28682873.

[13] Huang G.F, Wong J.W.C, Wu Q.T, Nagar B.B. Effect of $\mathrm{C} / \mathrm{N}$ on composting of pig manure with sawdust. Waste Manag. 2004; 24(8):805-813. 